\title{
Cancer Risk
}

National Cancer Institute

\section{Source}

National Cancer Institute. Cancer Risk. NCI Thesaurus. Code C18077.

The probability that exposure to some agent or substance will adversely transform cells

to replicate and form a malignant tumor. (EPA T erminology Reference System) 